\title{
Article \\ Trends of Ground-Level Ozone in New York City Area during 2007-2017
}

\author{
Subraham Singh (1) and Ilias G. Kavouras *(i)
}

check for updates

Citation: Singh, S.; Kavouras, I.G. Trends of Ground-Level Ozone in New York City Area during 2007-2017. Atmosphere 2022, 13, 114. https: / /doi.org/10.3390/ atmos13010114

Academic Editor: Giacomo Alessandro Gerosa

Received: 26 December 2021

Accepted: 10 January 2022

Published: 12 January 2022

Publisher's Note: MDPI stays neutral with regard to jurisdictional claims in published maps and institutional affiliations.

Copyright: () 2022 by the authors. Licensee MDPI, Basel, Switzerland. This article is an open access article distributed under the terms and conditions of the Creative Commons Attribution (CC BY) license (https:/ / creativecommons.org/licenses/by/ $4.0 /)$.
Department of Environmental, Occupational and Geospatial Health Sciences, City University of New York Graduate School of Public Health and Health Policy, 55 West 125th Street, New York, NY 10027, USA; subraham.singh25@sph.cuny.edu

* Correspondence: ilias.kavouras@sph.cuny.edu

\begin{abstract}
The spatiotemporal patterns of ground level ozone $\left(\mathrm{O}_{3}\right)$ concentrations in the New York City (NYC) metropolitan region for the 2007-2017 period were examined conjointly with local emissions of $\mathrm{O}_{3}$ precursors and the frequency of wildfires. Daily 8-h and 1-h $\mathrm{O}_{3}$ and nitric oxide (NO) concentrations were retrieved from the US Environmental Protection Agency (EPA) Air Data. Annual emission inventories for 2008 and 2017 were acquired from EPA National Emissions Inventory (NEI). The number and area burnt by natural and human-ignited wildfires were acquired from the National Interagency Fire Center (NIFC). The highest daily 8-h max $\mathrm{O}_{3}$ concentrations varied from 90 to 111 parts per billion volume (ppbv) with the highest concentrations measured perimetrically to NYC urban agglomeration. The monthly 8-h max $\mathrm{O}_{3}$ levels have been declining for most of the periurban sites but increasing (from +0.18 to $+1.39 \mathrm{ppbv} /$ year) for sites within the urban agglomeration. Slightly higher $\mathrm{O}_{3}$ concentrations were measured during weekend than those measured during the weekdays in urban sites probably due to reduced $\mathrm{O}_{3}$ titration by NO. Significant reductions of locally emitted anthropogenic nitrogen oxides $\left(\mathrm{NO}_{\mathrm{x}}\right)$ and volatile organic compounds (VOCs) may have triggered the transition from VOC-limited to $\mathrm{NO}_{\mathrm{X}}$-limited conditions, with downwind VOCs sources being critically important. Strong correlations between the monthly 8-h max $\mathrm{O}_{3}$ concentrations and wildfires in Eastern US were computed. More and destructive wildfires in the region were ignited by lightning for years with moderate and strong La Niña conditions. These findings indicate that climate change may counterbalance current and future gains on $\mathrm{O}_{3}$ precursor's reductions by amending the VOCs-to- $\mathrm{NO}_{\mathrm{x}}$ balance.
\end{abstract}

Keywords: annual trend; day-of-the-week variation; ozone precursors; urban environment; wildfires

\section{Introduction}

Ground-level ozone $\left(\mathrm{O}_{3}\right)$ negatively impacts human health across life stages, natural ecosystems, and climate [1,2]. Ozone is a strong oxidative agent that reacts with proteins and lipids in the airways lining fluid of the lung and compromised lung function [3-5]. Early-life exposure to $\mathrm{O}_{3}$ affects the growth and function of developing lungs and may promote the asthma phenotype in the first year of life [6-8]. Children exposed to $\mathrm{O}_{3}$ are also more likely to have airway hyper responsiveness [9]. $\mathrm{O}_{3}$ exposures have been consistently shown to increase asthma medication use, mortality, emergency department (ED) visits, and hospitalizations by exacerbating asthma and chronic obstructive pulmonary disease (COPD) [1,10].

$\mathrm{O}_{3}$, a secondary pollutant, is produced from the daytime oxidation of irradiated mixtures of volatile organic compounds (VOCs) and nitrogen oxides $\left(\mathrm{NO}_{\mathrm{x}}\right)\left(\mathrm{NO}+\mathrm{NO}_{2}=\mathrm{NO}_{\mathrm{x}}\right)$ (precursors, thereafter). $\mathrm{O}_{3}$ levels increase as VOCs levels increase, while increasing $\mathrm{NO}_{\mathrm{x}}$ levels may either generate or titrate $\mathrm{O}_{3}$ depending on instantaneous $\mathrm{VOC} / \mathrm{NO}_{\mathrm{x}}$ ratio (in parts per million carbon (ppmC)/parts per million (ppm)) [11]. VOCs and $\mathrm{NO}_{x}$ are emitted from fossil and contemporary fuel combustion in anthropogenic activities and wildfires. 
Isoprene and terpenes are the predominant biogenic VOCs released by vegetation. $\mathrm{O}_{3}$ concentrations vary from $20-40 \mathrm{ppbv}$ in remote continental areas up to 100-200 ppbv in areas downwind of metropolitan urban areas [12]. On a local scale, there is a strong spatiotemporal gradient of $\mathrm{O}_{3}$ levels with the lowest concentration being measured at the proximity of combustion sources (e.g., downtown or city center) when $\mathrm{O}_{3}$ is titrated by nitric oxide $(\mathrm{NO})$, and the highest $\mathrm{O}_{3}$ levels at downwind locations in the late afternoon [13].

Because ambient $\mathrm{O}_{3}$ levels are regulated by the National Ambient Air Quality Standards (NAAQS) pursuant to the Clean Air Act (CAA) and its amendments, strategies, and measures to reduce both VOCs and $\mathrm{NO}_{\mathrm{X}}$ emissions from anthropogenic sources have been implemented over the past four decades [14]. As a result, ambient $\mathrm{O}_{3}$ levels declined considerably in many heavily $\mathrm{O}_{3}$ polluted areas but reached a plateau and in many urban and peri-urban areas is trending upwards, lately [15]. Changes in local meteorology did not account for $\mathrm{O}_{3}$ trends in urban and continental background locations [16]. On a global and regional scale, increasing emissions of VOCs and $\mathrm{NO}_{\mathrm{X}}$ in developing countries amplified background $\mathrm{O}_{3}$ concentrations [17]. More frequent and intense wildfires, amplified by climate change, are also linked to episodic events of high $\mathrm{O}_{3}$ pollution in downwind locations $[18,19]$. Lastly, spatiotemporal changes of $\mathrm{NO}_{\mathrm{x}}$ and $\mathrm{VOC}$ emissions and their relative abundance may also contribute to the observed positive trends as the intensity of $\mathrm{O}_{3}$ destruction by $\mathrm{NO}$ titration is declining and more VOCs will increase $\mathrm{O}_{3}$ [15].

The New York-Newark-Jersey City, NY-NJ-PA Metro Area is the largest and most populous in North America (area of 17,314 $\mathrm{km}^{2}$ and 19,216,182 residents in 2020) [20]. It encompasses New York City (NYC), Long Island, Mid and Lower Hudson Valley, and major urban areas in New Jersey. The region is a moderate non-attainment area exceeding the $2015 \mathrm{NAAQS} \mathrm{O}_{3}$ standard of $70 \mathrm{ppbv}$ [21]. The aims of this study were (i) to characterize the spatial and temporal variation of $\mathrm{O}_{3}$ in the NYC region using quantitative statistical tools and (ii) to investigate the impact of local emissions trends and wildfires on $\mathrm{O}_{3}$ levels, with the overall objective of delineating the atmospheric conditions and sources at local and regional scale contributing to $\mathrm{O}_{3}$ pollution in NYC.

\section{Materials and Methods}

\subsection{Air Pollution Data Acquisition and Processing}

Daily 8-h max $\mathrm{O}_{3}$ measurements at sixteen (16) sites in the New York City metropolitan region for the 2007-2017 period were retrieved from the U.S. Environmental Protection Agency (USEPA) Air Data system (Table 1) [22]. In addition, hourly $\mathrm{O}_{3}$ and nitric oxide (NO) concentrations were obtained for sites with concurrent measurements for the monitoring period. Figure 1 shows the locations of the air quality monitoring sites, population, and major traffic corridors. There were:

- Seven sites are operated by the New York State Department of Environmental Conservation, four of them within NYC (City College of New York in West Harlem) (\#1), Pfizer Lab in Bronx (\#3) and Queens College in Queens (\#4), with more than 1.5 million of people within $8 \mathrm{~km}$ of each site; White Plains in Westchester (\#6, about 450,000 residents within $8 \mathrm{~km}$ ) County in Figure 1 and three of them in Suffolk County, Long Island (\#10, \#11 (500,000-700,000 people) and \#12 (57,000 people) in Figure 1);

- Six sites were operated by the New Jersey Department of Environmental Protection. Three of the sites (\#2, \#5 and \#15) were in populated urban settings (from 600,000 to 2,500,000 people within $8-\mathrm{km}$ radius), while the remaining three were further away from New York City (\#13,\#14 and \#16, less than 275,000 people within 8-km); and

- Three sites along the US Interstate-95 highway to Bridgeport, CT, operated by the Connecticut Department of Environmental Quality (\#7, \#8, and \#9 in Figure 1, with 180,000 to 280,000 people living within an 8-km radius).

Ambient $\mathrm{O}_{3}$ concentrations were photometrically measured with approved federal equivalent methods. 
Table 1. The characteristics (ID \#, name, type, latitude, longitude, elevation, distance to CCNY site, and population within an 8-miles radius of $\mathrm{O}_{3}$ monitoring sites in the study area.

\begin{tabular}{|c|c|c|c|c|c|c|}
\hline ID \# & Site Name & $\begin{array}{l}\text { Latitude } \\
\quad\left({ }^{\circ} \mathrm{N}\right)\end{array}$ & $\begin{array}{l}\text { Longitude } \\
\left({ }^{\circ} \mathrm{W}\right)\end{array}$ & $\begin{array}{l}\text { Elevation } \\
\text { (m) }\end{array}$ & $\begin{array}{l}\text { Distance from } \\
\text { CCNY Site (km) }\end{array}$ & $\begin{array}{c}\text { Population } \\
(<8 \mathrm{~km})\end{array}$ \\
\hline \multicolumn{7}{|c|}{ NYC urban sites } \\
\hline 1 & CCNY & 40.819 & 73.948 & 45 & - & $4,117,668$ \\
\hline 2 & Leonia & 40.870 & 73.991 & 1 & 6.7 & $2,675,227$ \\
\hline 3 & Pfizer Lab Site ${ }^{a}$ & 40.867 & 73.878 & 31 & 7.8 & $2,900,231$ \\
\hline 4 & Queens College $^{\text {a }}$ & 40.736 & 73.821 & 25 & 13.9 & $2,825,439$ \\
\hline 5 & Bayonne ${ }^{a}$ & 40.670 & 74.126 & 3 & 22.5 & $1,426,212$ \\
\hline \multicolumn{7}{|c|}{ Peri-urban sites } \\
\hline 6 & White Plains & 41.051 & 73.763 & 64 & 31.5 & 452,018 \\
\hline 7 & $\begin{array}{c}\text { Greenwich Point } \\
\text { Park }\end{array}$ & 41.004 & 73.585 & 3 & 37.5 & 283,192 \\
\hline 8 & Sherwood Island ${ }^{a}$ & 41.118 & 73.336 & 4 & 62.4 & 188,692 \\
\hline 9 & Stratford & 41.152 & 73.103 & 3 & 79.5 & 288,077 \\
\hline 10 & Babylon & 40.745 & 73.419 & 27 & 45.2 & 671,479 \\
\hline 11 & Holtsville & 40.827 & 73.057 & 45 & 75.2 & 455,965 \\
\hline 12 & Riverhead & 40.960 & 72.712 & 31 & 105.7 & 57,381 \\
\hline 13 & Ramapo & 41.058 & 74.255 & 3047 & 37.8 & 265,429 \\
\hline 14 & Chester $^{\mathrm{a}}$ & 40.787 & 74.676 & 278 & 61.3 & 205,712 \\
\hline 15 & Rutgers University & 40.462 & 74.429 & 19 & 56.6 & 619,552 \\
\hline 16 & $\begin{array}{l}\text { Monmouth } \\
\text { University }\end{array}$ & 40.277 & 74.005 & 8 & 60.5 & 240,959 \\
\hline
\end{tabular}

${ }^{a}$ Hourly $\mathrm{O}_{3}$ and $\mathrm{NO}$ measurements were retrieved.

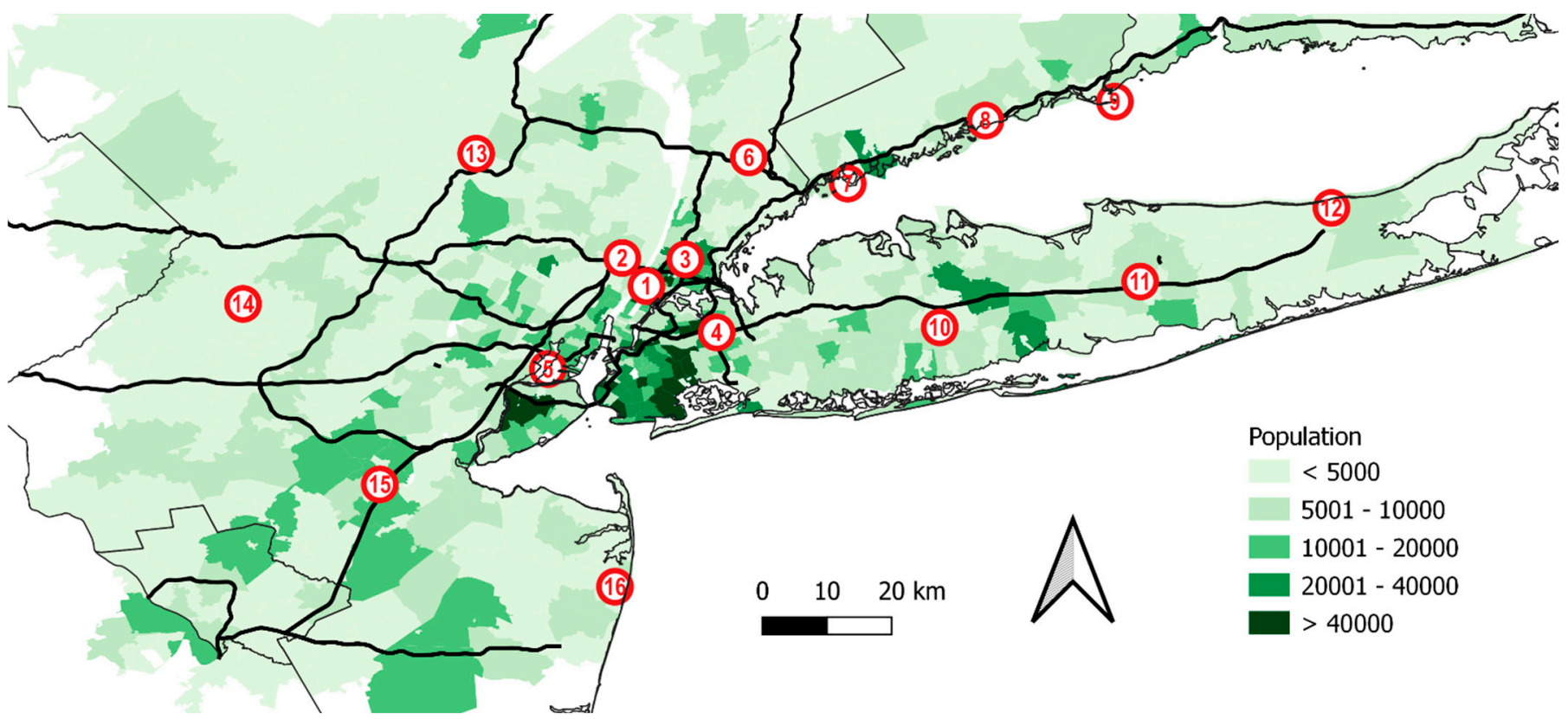

Figure 1. The locations of air quality sites, 2019 population (by US Census track [20]) and primary road network in the study area. The numbers in the circle refer to sites ID\# in Table 1.

\subsection{Emissions Inventories and Wildfires}

The 2008 and $2017 \mathrm{NO}_{\mathrm{x}}$ and VOCs emissions for New York, New Jersey, and Connecticut were obtained from the USEPA National Emissions Inventory (NEI). It includes emissions from point, area, mobile (on- and off-road), and event-specific sources based on source activity data provided by the state, local, and tribal air agencies through the Emissions Inventory System (EIS). Emissions have been reported by EIS sectors since 2008 as described in the Source Classification Codes (SCCs). SCCs are source-specific processes 
or functions that emit air pollutants. For this study, 2008 and 2017 NEI data by EIS sectors were grouped into fourteen source types as follows: agriculture/livestock waste; biogenics (including vegetation and soil); bulk gasoline terminals; commercial cooking; fires (including agricultural, prescribed, and wildfires); commercial, electrical generation, industrial and residential fuel combustion; gas stations; industrial and non-industrial processes; mobile sources, solvent fugitive emissions; and waste disposal. The number of human- and lightning-ignited wildfires and area burnt for the 2007-2017 period by year for each of the eleven Geographic Area Coordinating Group (GACG) were obtained from the National Interagency Fire Center (NIFC) [23]. The study area is part of the Eastern Area Coordination Center (EACC) that includes a total of twenty (20) states: Connecticut, Delaware, Illinois, Indiana, Iowa, Maine, Massachusetts, Maryland, Michigan, Minnesota, Missouri, New Hampshire, New Jersey, New York, Ohio, Pennsylvania, Rhode Island, Vermont, West Virginia, and Wisconsin.

\subsection{Data Analysis}

Ambient daily 8-h $\max \mathrm{O}_{3}$ concentrations were tested for normality using the ShapiroWilk test. The significance of difference among sites was assessed with the non-parametric Kruskal-Wallis at $\alpha=0.05$. The daily 8 -h $\max \mathrm{O}_{3}$ absolute $(\Delta \mathrm{C})$ and the percent relative (\% $\mathrm{C} / \mathrm{Ref})$ concentration differences and the coefficient of divergence (COD) were computed [24]. The CCNY (located in City College of New York) (Site \#1 in Figure 1) was the reference site because of its central location to the study area. COD values vary from 0 to 1 , with high COD values being indicative of spatial gradient. The paired $\Delta \mathrm{C}$ between two sites were used to determine whether concentrations change simultaneously among the sites over time. The $\% \Delta \mathrm{C} / \mathrm{C}_{\mathrm{Ref}}$ of 24 -h paired concentration was computed to assess systematic differences between the sites and site-to-site variation, respectively [24]. COD was used to assess the spatial uniformity of measurements with respect to the concentration levels [25].

The monthly 8-h max $\mathrm{O}_{3}$ concentration was computed for months with more than $75 \%$ of daily 8-h max $\mathrm{O}_{3}$ measurements. It has been previously used to examine the effect of wildfires on $\mathrm{O}_{3}$, compliance with NAAQS, and to smooth the effects of local meteorology and short-term changes in local emissions $[24,25]$. The annual trend was computed using the de-seasonalized monthly 8-h max $\mathrm{O}_{3}$ concentrations by applying the non-parametric sequential Mann-Kendall test at a confidence level of 95\% [26,27].

Hourly $\mathrm{NO}$ and $\mathrm{O}_{3}$ concentrations were used to compute the morning $\mathrm{NO}_{3} \mathrm{O}_{3}$ crossover time (tNOxO3) (in $\mathrm{h}$ ) and the $\mathrm{O}_{3}$ accumulation time (tO3_acc) (in $\mathrm{h}$ ) as follows: (i) the $\mathrm{tNO}_{\mathrm{X}} \mathrm{O} 3$ is the time of the day where $\mathrm{NO}$ and $\mathrm{O}_{3}$ profiles intersected after the early morning NO peak; and (ii) the tO3_acc is the time of the day with the highest $\mathrm{O}_{3}$ concentration [11] The ozone accumulation rate (in $\mathrm{ppbv} \mathrm{O}_{3} / \mathrm{h}$ ) was computed as follows:

$$
\text { Acc.Rate }=\left(\left[\mathrm{O}_{3}\right]_{\left(\mathrm{tO} 3 \_\mathrm{acc}\right)}-\left[\mathrm{O}_{3}\right]_{(\mathrm{tNOxO} 3)}\right) /\left(\mathrm{tO} 3 \_\mathrm{acc}-\mathrm{tNO} \mathrm{tO}_{\mathbf{X}}\right)
$$

where $\left[\mathrm{O}_{3}\right]_{\mathrm{tNOxO} 3}$ and $\left[\mathrm{O}_{3}\right]_{\mathrm{tO}} 3_{\text {acc }}$ are the $\mathrm{O}_{3}$ concentrations at $\mathrm{NOxO} 3$ crossover and $\mathrm{O}_{3}$ accumulation times of the day, respectively.

The two-tailed Spearman correlation coefficient was computed to assess the relationship between wildfires and annual 8-h max $\mathrm{O}_{3}$ concentration. Analyses were done using SPSS (Version 26) (IBM Analytics, Armonk, NY, USA) and Origin Pro (version 9.1) (Origin Lab, Northampton, MA, USA).

\section{Results}

\subsection{Spatial and Temporal Trends}

Figure 2 shows the time series of monthly 8-h max $\mathrm{O}_{3}$ at the sixteen sites. Monthly 8-h max $\mathrm{O}_{3}$ levels at all sites ranged from a $25 \mathrm{ppbv}$ during the winter months (December to February) to 90 at Pfizer Lab (\#3), 91 ppbv at CCNY (\#1) and Riverside (\#12), 95 ppbv at Leonia (\#2), 94 ppbv at Ramapo (\#), 96 ppbv at Queens College (\#4), Holtsville (\#11) and Chester (\#14), 97 ppbv at Monmouth University (\#16), 101 at White Plains (\#6), 102 ppbv 
at Rutgers Univ (\#15), 103 ppbv at Stratford (\#8) and Sherwood Island (\#9), 105 ppbv at Greenwich Point (\#7), 111 ppbv in Bayonne (\#5) and 114 ppbv in Babylon (\#10). The highest monthly $\mathrm{O}_{3}$ mixing ratios were typically measured in June and July. Note that $\mathrm{O}_{3}$ was measured during April-October at Riverhead in NY, Ramapo and Monmouth University in NJ, and all three sites in Connecticut.
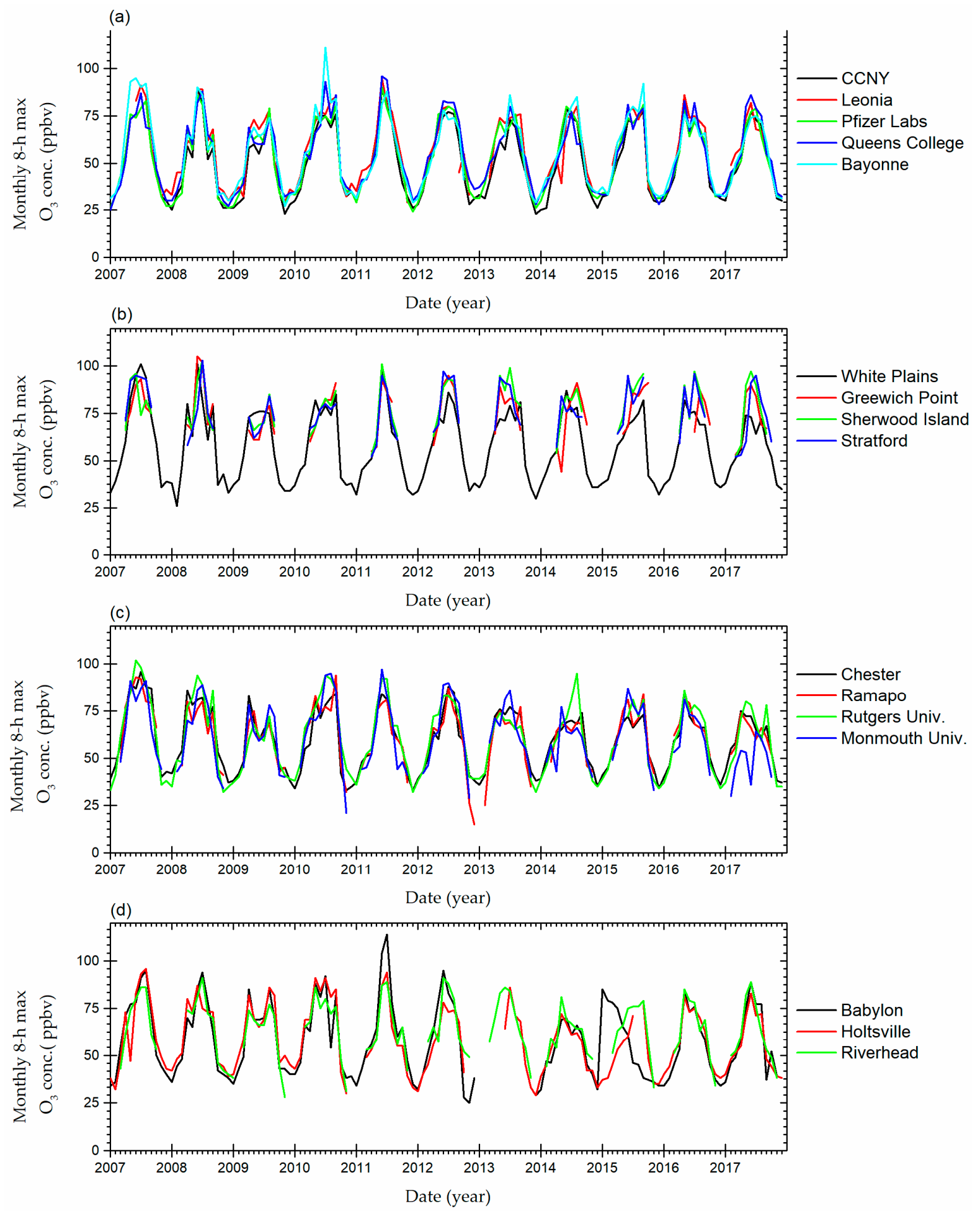

Figure 2. Times series of monthly 8-h max $\mathrm{O}_{3}$ (in ppbv) at (a) urban sites; (b) peri-urban sites north of NYC and in Connecticut; (c) peri-urban sites in NJ and (d) peri-urban sites in Long Island. 
Table 2 shows the 2017 8-h max $\mathrm{O}_{3}$ concentration (in ppbv), the site-specific COD value, median (and standard deviation $(\sigma))$ of absolute $(\Delta C)$ and relative $(\% \Delta C /$ Ref) concentration differences (relative to CCNY air quality monitoring site) and the annual trends of monthly 8-h max $\mathrm{O}_{3}$ levels for each site (ppbv/year). The 8-h maximum $\mathrm{O}_{3}$ concentrations for 2017 varied from $60 \mathrm{ppbv}$ for the coastal site upwind of New York City in Monmouth University (\#16) to 81 ppbv for the two coastal sites downwind of New York City in Connecticut (Sherwood Island (\#8) and Stratford (\#9)). The sites were grouped in two clusters based on spatiotemporal similarities to the reference site (\#1 at CCNY in Manhattan). The first cluster was composed of sites within the NYC urban area (\#3-5), with low COD values (from 0.10 to 0.14$), \Delta C(2-4 \mathrm{ppbv})$ and $\% \Delta C / C_{\text {ref }}$ (from 6 to $12 \%$ ) indicating the lack of a spatial gradient within the densely populated area. For most of these sites (except for Bayonne (\#5) that is located on the south of the densely NYC populated area), the 8-h max $\mathrm{O}_{3}$ concentrations were increasing from 0.18 to $1.39 \mathrm{ppbv} /$ year. For sites located perimetrically to $\mathrm{NYC}$, slightly higher COD (from 0.13 to 0.22 ), $\Delta \mathrm{C}$ (from 5 to $9 \mathrm{ppbv}$ ) and $\% \Delta \mathrm{C} / \mathrm{C}_{\text {ref }}$ (from 16 to $26 \%$ ) suggested a weak spatial trend particularly across the west-east axis relative to $\mathrm{NYC}$. The 8-h max $\mathrm{O}_{3}$ concentrations declined from -0.25 to $-1.82 \mathrm{ppbv} /$ year except for two of the nearest to NYC sites in Connecticut from +0.03 (\#7) and +0.43 (\#8) ppbv/year.

Table 2. The 2017 8-h max $\mathrm{O}_{3}$ concentration, mean COD, median (and standard deviation $(\sigma)$ ) $o \varphi$ absolute $(\Delta \mathrm{C})$ and relative (\% $\% \mathrm{C} /$ Ref) concentration differences (compared to CCNY site) and annual trends of 8-h $\max \mathrm{O}_{3}$ concentrations.

\begin{tabular}{|c|c|c|c|c|c|c|}
\hline & Site No and Location & $\begin{array}{c}2017 \text { 8-h Max } \mathrm{O}_{3} \\
\text { (ppbv) }\end{array}$ & COD & $\begin{array}{c}\Delta \mathrm{C} \\
(\operatorname{Median}(\sigma))\end{array}$ & $\begin{array}{c}\% \Delta \mathrm{C} / \mathrm{C}_{\mathrm{ref}} \\
(\operatorname{Median}(\sigma))\end{array}$ & $\begin{array}{l}\text { Annual Trend } \\
\text { (ppbv/year) }\end{array}$ \\
\hline \multicolumn{7}{|c|}{ NYC urban sites } \\
\hline 1 & CCNY & 70 & n.c. & n.c. & n.c. & $0.24 *$ \\
\hline 2 & Leonia & 74 & 0.12 & $4(5.0)$ & 11 (129.7) & 1.39 ** \\
\hline 3 & Pfizer Laboratories & 69 & 0.10 & $2(3.8)$ & $6(107.3)$ & $0.31 * *$ \\
\hline 4 & Queens College & 79 & 0.14 & $4(5.1)$ & $12(119.1)$ & 0.18 \\
\hline 5 & Bayonne & 67 & 0.12 & $2(5.2)$ & $7(108.1)$ & -0.28 \\
\hline \multicolumn{7}{|c|}{ Peri-urban sites } \\
\hline 6 & White Plains & 72 & 0.18 & $6(6.6)$ & $21(92.5)$ & $-0.25 *$ \\
\hline 7 & Greenwich Point Park & 74 & 0.14 & $8(6.4)$ & $20(32.4)$ & $0.03^{\mathrm{a}}$ \\
\hline 8 & Sherwood Island & 81 & 0.13 & $7(7.3)$ & $18(30.1)$ & $0.43^{*, a}$ \\
\hline 9 & Stratford & 81 & 0.16 & $9(7.7)$ & $23(38.4)$ & $0.01^{\mathrm{a}}$ \\
\hline 10 & Babylon & 77 & 0.19 & $6(7.3)$ & $20(161.4)$ & $-0.69^{* *}$ \\
\hline 11 & Holtsville & 71 & 0.22 & $7(12.0)$ & $23(199.1)$ & $-1.82 * *$ \\
\hline 12 & Riverhead & 76 & 0.19 & $8(8.9)$ & $23(102.9)$ & $-0.41 * *$ \\
\hline 13 & Ramapo & 66 & 0.16 & $5(9.0)$ & $16(164.2)$ & $0.01^{\mathrm{a}}$ \\
\hline 14 & Chester & 70 & 0.22 & $8(8.1)$ & $27(150.2)$ & $-0.82 * *$ \\
\hline 15 & Rutgers University & 75 & 0.20 & $8(6.7)$ & $26(142.4)$ & $-0.41 *$ \\
\hline 16 & Monmouth University & 60 & 0.17 & $6(9.0)$ & $18(154.2)$ & $-0.73^{* *}$ \\
\hline
\end{tabular}

n.c.: not computed. ${ }^{a}$ Data available only from April to October. ${ }^{*} p<0.05,{ }^{* *} p<0.001$.

Figure 3 shows the mean $( \pm 3 \times$ standard error) ozone weekend-to-weekday effect (OWE) ratio of average maximum $\mathrm{O}_{3}$ concentrations for each site. OWE values higher than one indicate that weekend $\mathrm{O}_{3}$ concentrations were higher than those measured during the weekdays. For all NYC urban sites, the OWE ratio was higher than 1 (from 1.04 to 1.07), indicating that weekend $\mathrm{O}_{3}$ levels were higher than those measured during weekend. For two of the most populated peri-urban sites (White Plains (\#6) and Babylon (\#10)), the OWE ratio was also higher than 1 (1.02 and 1.03, respectively), and less than one for the remaining peri-urban sites. 


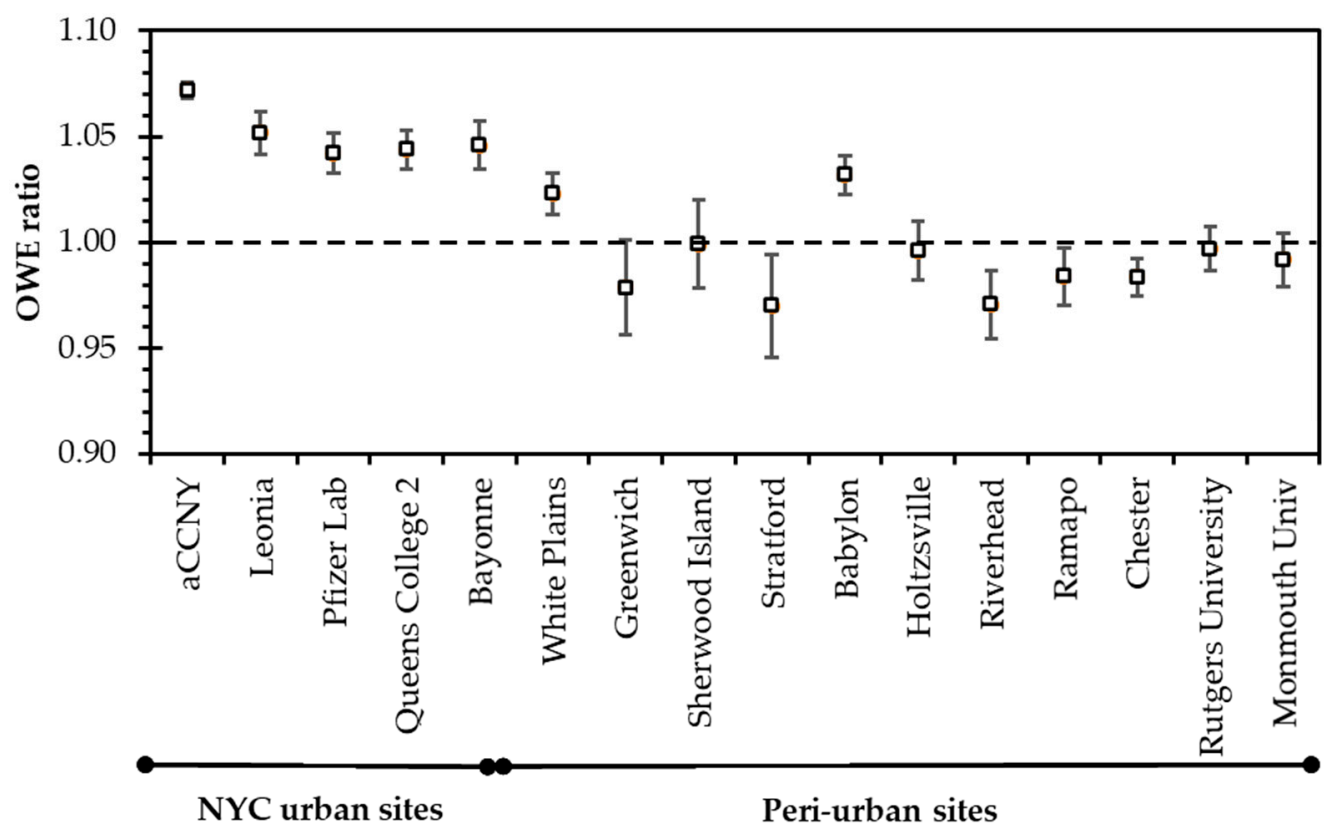

Figure 3. The mean $( \pm 3 \times$ standard error) ozone weekend-to-weekday effect (OWE) ratio of average maximum $\mathrm{O}_{3}$ concentrations for each site.

Figure 4 presents the day-of-week variation of the morning $\mathrm{NOxO}_{3}$ crossover time $\left(t_{\mathrm{NOxO}}\right)$, the $\mathrm{O}_{3}$ accumulation time ( $\left.\mathrm{t}_{\mathrm{O} 3 \_a c c}\right)$ and the $\mathrm{O}_{3}$ accumulation rate for (a) Queens College (NYC urban site (\#4)) and (b) Chester (peri-urban site (\#14)). For Queens College site, the $\mathrm{tNOxO} 3$ crossover was observed at between 7:00 and 9:00 am and $\mathrm{O}_{3}$ accumulated for six hours during weekdays and Saturday (Figure 4a). During Sunday, $\mathrm{O}_{3}$ formation was not hampered because of low NO levels. The weekend NO concentrations (24-h mean: 1.4-1.8 ppbv; 1-h max: 3.7-6.9 ppbv) was up to three times lower than that measured during weekdays (24-h mean: 2.7-3.4 ppbv; 1-h max: 7.7-14.0 ppbv). The lowest accumulation rate observed on Sunday $(1.24 \mathrm{ppbv} / \mathrm{h})$ was counterbalanced by the longer accumulation period, resulting in elevated $\mathrm{O}_{3}$ concentrations. Because of the lack of titration in the early morning, the $\mathrm{O}_{3}$ overnight carryover on weekend (1-h: 18.6-23.4 ppbv) was higher than that during weekdays (1-h: 13-16.7 ppbv), adding to higher $\mathrm{O}_{3}$ concentrations in weekend.

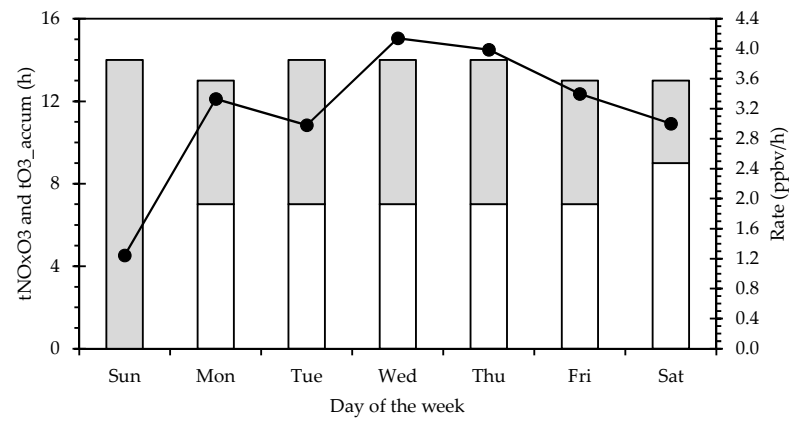

$\square$ tNOxO3 $\square$ tO3_accum $\rightarrow$-Rate

(a)

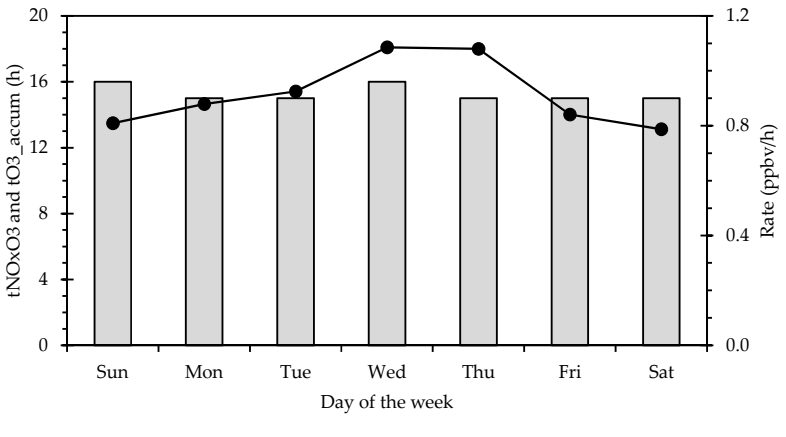

$\square \mathrm{tNOxO3} \square \mathrm{tO} 3$ accum $\rightarrow$-Rate

(b)

Figure 4. The day-of-week variation of the morning $\mathrm{NO}-\mathrm{O}_{3}$ crossover time (tNOxO3), the $\mathrm{O}_{3}$ accumulation time (tO3_acc) (h), and the $\mathrm{O}_{3}$ accumulation rate (ppbv/h) for (a) Queens College (Site \#10) and (b) Chester (Site \#4).

For Chester (Figure 4b), NO levels were minimal during weekends (1-h max levels $<0.2 \mathrm{ppbv}$ ) and less than $1 \mathrm{ppbv}$ during weekdays. As such, there was no $\mathrm{O}_{3}$ 
titration, with prolonged periods of ozone accumulation albeit at low accumulation rates (0.81-1.08 ppbv/h) for both weekends and weekdays. Moreover, the $\mathrm{O}_{3}$ overnight carryover (28.5-31.3 ppbv) did not vary among different days of the week.

\section{2. $\mathrm{O}_{3}$ Precursors Emissions and Wildfires}

Figure 5 shows the emission fraction (source category emission divided by the total emissions) of $\mathrm{NO}_{\mathrm{x}}$ and VOCs emissions in 2008 and 2017 in fifteen categories including anthropogenic combustion processes, wildfires, and biogenic emissions. In total, $\mathrm{NO}_{\mathrm{x}}$ emissions declined from 766,498 tons in 2008 to 89,209 tons in 2017. VOCs emissions also significantly declined, from 1,341,849 tons in 2008 to 213,272 tons in 2017 . However, the relative abundance of source categories on both $\mathrm{NO}_{\mathrm{x}}$ and $\mathrm{VOC}$ s remained unchanged Biogenic (e.g., isoprene, terpenes) VOCs was the predominant source (approximately $40 \%$ in 2008 and above $50 \%$ in 2017) followed by combustion-related mobile sources (about $30 \%$ in 2008 and less than $20 \%$ in 2017) and fugitive solvent emissions (about $20 \%$ for 2008 and 2017). For $\mathrm{NO}_{\mathrm{x}}$, mobile emissions (more than 76.5\%) dominated both 2008 and 2017 emissions with minor quantities from other fossil and contemporary fuel sources (Figure 5b). These trends were consistent with the declining $\mathrm{NO}_{\mathrm{x}}$ levels. VOCs levels may also decrease albeit the chemical content may have been moderately altered.

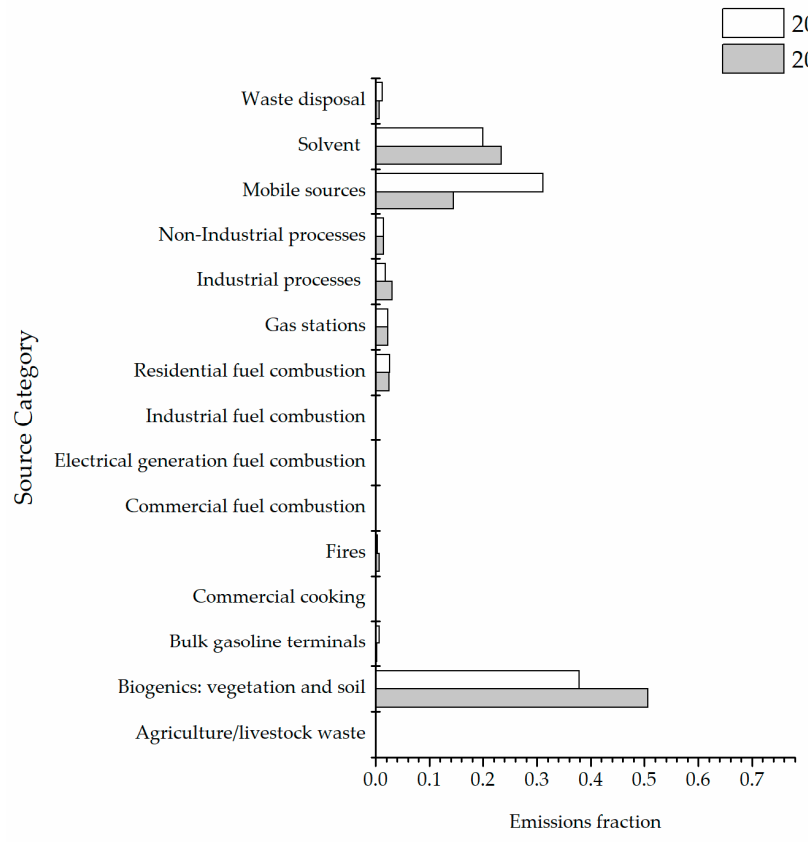

(a)

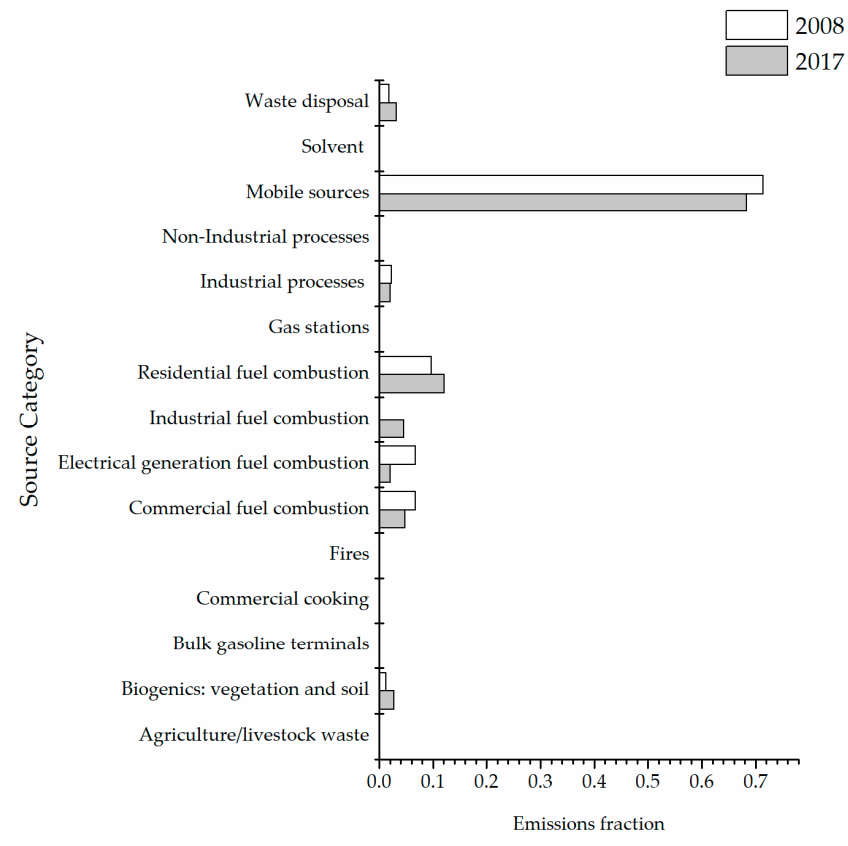

(b)

Figure 5. The relative abundance of (a) VOCs and (b) $\mathrm{NO}_{x}$ by source category in NY, NJ and CT in 2008 and 2017.

Table 3 shows the Spearman correlation coefficient of $\mathrm{O}_{3}$ concentrations, the number of and area burnt by fires within the areas managed by the ten GACC coordinating centers. Moderate to strong correlations were computed for the number $(0.91, p<0.001)$ and area $(0.60, p=0.01)$ burnt by lightning-ignited fires in the Eastern Area followed by fires in the Southern Area coordination center (number: 0.80, $p=0.003$ ) encompassing all states east of the Mississippi River and adjacent westerly states. Weaker correlations were computed for human-ignited wildfires in the same regions. It is noteworthy that prescribed burns in winter and spring for ecological management and to manage biomass fuel on the forest floor account for most of the human-induced fires in the Southern area. The Spearman correlation coefficient declined for wildfires further away from the study area 
Table 3. Spearman correlation coefficients of monthly 8-h max $\mathrm{O}_{3}$ concentrations and lightning, the number and area burnt by human-induced wildfires in regional GACG coordinating centers.

\begin{tabular}{lcccc}
\hline \multirow{2}{*}{ GACG Coordinating Centers * } & \multicolumn{2}{c}{ Number } & \multicolumn{2}{c}{ Area Burnt } \\
& Lightning & Human & Lightning & Human \\
\hline Eastern Area & $0.91^{* * *}$ & 0.47 & 0.60 & 0.58 \\
Southern Area & $0.80^{* *}$ & 0.24 & 0.44 & 0.41 \\
Northern Rockies & 0.00 & 0.08 & 0.36 & 0.31 \\
Southwest & 0.46 & 0.06 & -0.11 & 0.18 \\
Rocky Mountain & 0.41 & 0.25 & 0.44 & 0.19 \\
Great Basin & 0.16 & 0.35 & 0.34 & 0.36 \\
Northwest & -0.48 & -0.29 & -0.08 & -0.10 \\
Northern California & -0.12 & -0.61 & 0.06 & -0.32 \\
Southern California & 0.17 & 0.36 & 0.39 & 0.16 \\
Alaska & 0.01 & -0.12 & -0.28 & -0.32 \\
\hline
\end{tabular}

* Eastern Area (Connecticut, Delaware, Illinois, Indiana, Iowa, Massachusetts, Maryland, Maine, Michigan, Minnesota, Missouri, New Hampshire, New Jersey, New York, Ohio, Pennsylvania, Rhode Island, Vermont, Wisconsin, and West Virginia); Southern Area (Virginia, North Carolina, South Carolina, Georgia, Florida, Kentucky, Tennessee, Alabama, Mississippi, Louisiana, Arkansas, Oklahoma except for Panhandle, Central and Eastern Texas); Northern Rockies (North Dakota, Montana and Idaho-north of the Salmon River, Yellowstone National Park, and a small portion of South Dakota); Southwest (Western Texas, New Mexico, and Arizona except for the Strip); Rocky Mountain (Kansas, Nebraska, North Dakota, Colorado, and Wyoming except for western Wyoming mountains); Great Basin (Utah, Nevada, Idaho-south of the Salmon River, the western Wyoming mountains, and the Arizona Strip); Northwest (Washington and Oregon). ${ }^{* *}$ Correlation is significant at the 0.01 level (two-tailed) ${ }^{* * *}$ Correlation is significant at the 0.001 level (two-tailed).

The annual variation of 8-h $\max \mathrm{O}_{3}$ concentration, number and area burnt by lightningignited wildfires in the Eastern and Southern GACG areas are presented in Figure 6a,c,d. Figure $6 \mathrm{~b}$ also shows the Oceanic Niño Index (ONI), the 3-month moving average sea surface temperature anomaly of the east-central tropical Pacific, near the International Dateline. ONI values $>+0.5$ are indicative of El Niño conditions, while ONI values $<-0.5{ }^{\circ} \mathrm{C}$ are characteristic of La Niña conditions. Overall, there were more naturally occurring wildfires in the Eastern and Southern area during La Niña periods in 2007-2008, 2010-2011 and recently, than years with El Niño conditions.

(a)

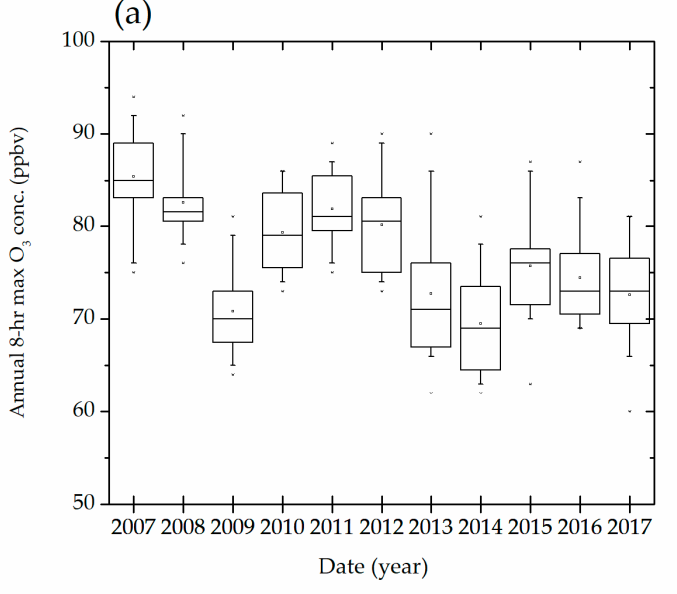

(b)

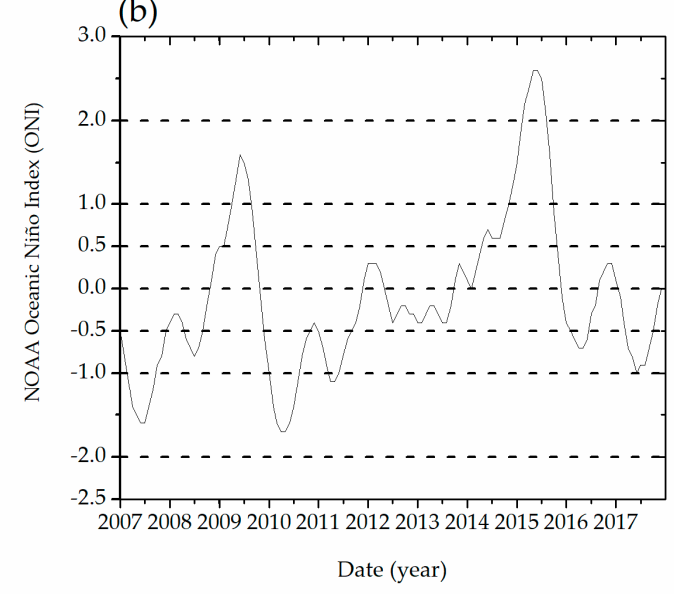

Figure 6. Cont. 
(c)

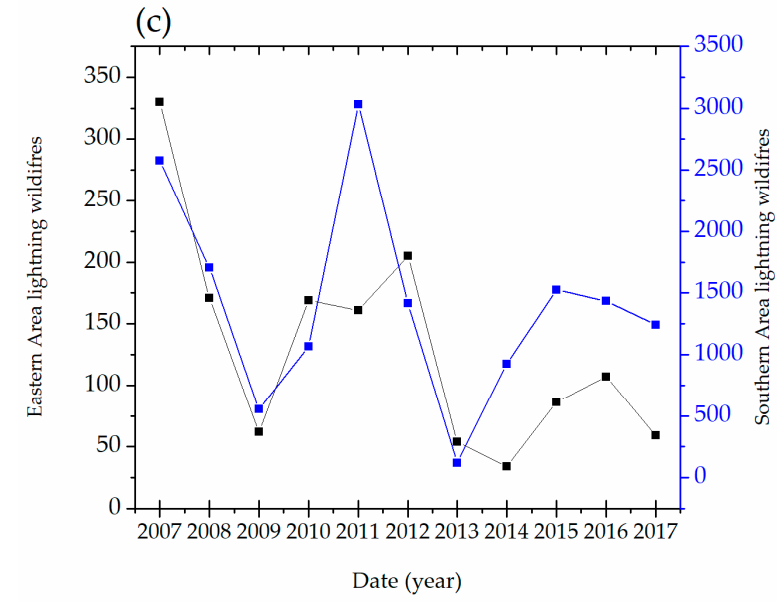

(d)

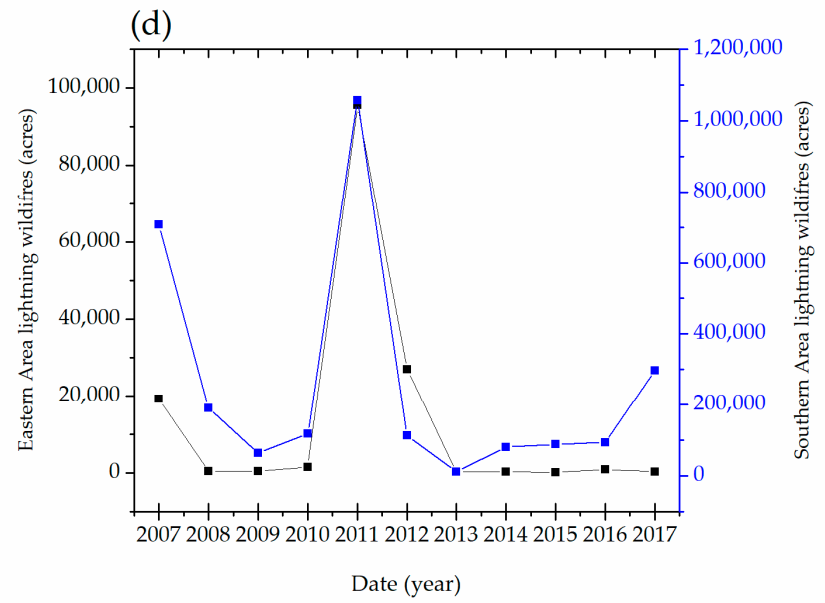

Figure 6. The (a) monthly 8-h $\max \mathrm{O}_{3}$ concentrations at the study area; (b) temperature abnormalities; (c) the number and (d) are burnt by wildfires in the Eastern and Southern areas during the period 2007-2017.

\section{Discussion}

In this study, we observed heterogeneity in the trends of monthly 8-h max $\mathrm{O}_{3}$ concentrations in urban and peri-urban sites in the NYC metropolitan area during 2007-2017. The declining trends in peri-urban sites are consistent with national $\mathrm{O}_{3}$ trends for less urbanized and rural areas [12]. These sites are usually located downwind of urban agglomerations where the highest 8-h max $\mathrm{O}_{3}$ concentrations were historically recorded. Conversely, an increasing trend of $\mathrm{O}_{3}$ was observed for the sites located within the urban agglomeration, areas that historically experienced high traffic-related $\mathrm{NO}_{\mathrm{x}}$ emissions and low $\mathrm{O}_{3}$ concentrations. This is also in agreement with increasing trends at urbanized locations across the US [12]. Similar trends were observed across the world with increasing concentrations in urban areas $\left(0.31 \mathrm{ppbv} /\right.$ year) and declining $\mathrm{O}_{3}$ levels in rural areas $(-0.23$ ppbv/year) over the past three decades $[28,29]$. The opposite trends in $\mathrm{O}_{3}$ concentrations in peri-urban and urban sites can be tentatively explained by declining anthropogenic VOCs and $\mathrm{NO}_{\mathrm{x}}$ emissions over the past decades, and the non-linear sensitivity of $\mathrm{O}_{3}$ formation to VOCsto- $\mathrm{NO}_{\mathrm{x}}$ instantaneous ratio [30]. In urban areas, $\mathrm{O}_{3}$ levels are conditioned by $\mathrm{NO}$ (from vehicular emission) titration in the early morning. Because of the significant declines in $\mathrm{NO}_{x}$ emissions, titration of $\mathrm{O}_{3}$ by $\mathrm{NO}$ was reduced leading to an increase of nighttime carryover $\mathrm{O}_{3}$ [30]. Ninneman and Jaffe [21] computed that the summertime ozone production efficiency in New York State rural sites increased in response to $\mathrm{NO}_{\mathrm{x}}$ reductions in $\mathrm{NO}_{\mathrm{x}}$-limited conditions. The VOCs-to- $\mathrm{NO}_{\mathrm{x}}$ ratio between 2008 and 2017 (based on EPA NEI) may have increased from $26.7 \%$ to $83.5 \%$ depending on VOCs composition that can transition from VOC-limited conditions to $\mathrm{NO}_{\mathrm{x}}$-limited for $\mathrm{O}_{3}$ formation. Using satellite measurements of $\mathrm{HCHO}$ and $\mathrm{NO}_{2}$, Jin et al. [15] estimated that transition from VOCs-limited to $\mathrm{NO}_{\mathrm{x}}$-limited conditions occurred within 40-60 km for NYC by 2013-2016, as compared to $80-120 \mathrm{~km}$ in the past, accompanied by the reversal of $\mathrm{O}_{3}$ weekend effect.

The transition from VOCs-limited to $\mathrm{NO}_{\mathrm{x}}$-limited conditions may be better delineated in $\mathrm{O}_{3}$ weekend effect. The average OWE effect for the urban areas was consistent with that observed in other US urban areas [31]. It has been attributed to the reduction in $\mathrm{NO}_{x}$ emissions from road traffic on weekends, particularly on Sundays, leading to a lower $\mathrm{O}_{3}$ titration by NO that also appears to be the dominant cause in NYC. VOCs emissions from recreational and residential activities may offset reduced traffic-related VOCs emissions in weekends allowing for longer $\mathrm{O}_{3}$ accumulation and production [11]. In peri-urban sites, there was no $\mathrm{O}_{3}$ weekend effect, in agreement with previous studies [30,31]. This was ascribed to the reduced NO titration throughout the week. Analysis of the 2018 summer $\mathrm{O}_{3}$ exceedances in NYC, accompanied by a series of heatwaves showed that shortly downwind of Manhattan and within the urban corridor, $\mathrm{O}_{3}$ formation transitioned to $\mathrm{NO}_{\mathrm{x}}$-limited 
conditions. Moreover, the combination of $\mathrm{NO}_{\mathrm{x}}$ and biogenic VOCs primarily contributed to high $\mathrm{O}_{3}$ levels [32].

We observed a strong correlation between $\mathrm{O}_{3}$ levels and the frequency of regional wildfires. Changes in local photochemistry and regional transport may also influence $\mathrm{O}_{3}$ trends. For the Northeastern US, ambient ozone concentrations were more dependent on ambient temperature (30\%) than anthropogenic $\mathrm{NO}$ emissions reductions $(10 \%)$ [33]. For the Northeast, which includes the study area, regional $\mathrm{O}_{3}$ transport $(60 \%)$ explained most of the $\mathrm{O}_{3}$ variability [33]. Transport from wildfires can modify $\mathrm{O}_{3}$ at receptor sites. It was previously observed that the 8-h max $\mathrm{O}_{3}$ concentration increased as the fire intensity increased due to the mixing of VOCs-rich wildfire plumes with $\mathrm{NO}_{x}[11,18,24]$. These conditions may further enhance the $\mathrm{NO}_{x}$ limited conditions in NYC yielding high $\mathrm{O}_{3}$ concentrations. Moreover, oxygenated VOCs released during wildfires (e.g., methoxy phenols) may react with $\mathrm{NO}_{x}$ to form stable peroxyacetyl nitrates (PANs) that permanently remove $\mathrm{NO}_{\mathrm{x}}$ and moderate downwind $\mathrm{O}_{3}$ levels $[24,32]$. The transition from El Niño to La Niña conditions over periods of two-three years of El Niño-Southern Oscillation (ENSO) is associated with increased wildfires in the US. This may be due to the accumulation of fresh biomass during the El Niño events including invasive grasses that trigger faster wildfire progression. During La Niña conditions in the following years, increased temperatures, reduced precipitation, and drought create conditions that promote fast-spreading wildfires [34].

\section{Conclusions}

The analysis showed increasing $\mathrm{O}_{3}$ concentrations in sites within urban agglomerations while $\mathrm{O}_{3}$ concentrations peri-urban have been declining. This was tentatively assigned to changes in the photochemical regime from VOC-limited to $\mathrm{NO}_{\mathrm{x}}$-limited conditions. The weekend-weekday $\mathrm{O}_{3}$ pattern indicated that reduced $\mathrm{O}_{3}$ titration by $\mathrm{NO}$ has been declining increasing the nighttime $\mathrm{O}_{3}$ carryover and promoting longer $\mathrm{O}_{3}$ accumulation periods. Moreover, a strong correlation of $\mathrm{O}_{3}$ levels with regional wildfires was computed. This was attributed to increased VOCs emissions and the formation of PANs in the smoke plume during transport and its mixing with ground-level air that can further augment $\mathrm{NO}_{\mathrm{x}}$-limited conditions. The frequency and magnitude of wildfires in the eastern US were related to the sequence of El-Nino and La Nina events, with more lightning-ignited fires during dry periods. To mitigate increasing $\mathrm{O}_{3}$ levels in densely populated areas, future emission control strategies should also consider the compounding global and regional effects of climate change.

Author Contributions: Conceptualization, I.G.K.; methodology, S.S. and I.G.K.; data curation, formal analysis, S.S.; writing—original draft preparation, S.S.; writing—review and editing, I.G.K.; supervision, I.G.K. All authors have read and agreed to the published version of the manuscript.

Funding: This research was partially funded by the Dean's Dissertation Award.

Institutional Review Board Statement: Not applicable.

Informed Consent Statement: Not applicable.

Data Availability Statement: Air pollutant data are available on US Environmental Protection Agency Air Data web page https: / / aqs.epa.gov / aqsweb/airdata/download_files.html (accessed on 1 October 2020).

Conflicts of Interest: The authors declare no conflict of interest. The funders had no role in the design of the study; in the collection, analyses, or interpretation of data; in the writing of the manuscript, or in the decision to publish the results. 


\section{References}

1. Vicedo-Cabrera, A.M.; Sera, F.; Liu, C.; Armstrong, B.; Milojevic, A.; Guo, Y.; Tong, S.; Lavigne, E.; Kyselý, J.; Urban, A.; et al. Short term association between ozone and mortality: Global two stage time series study in 406 locations in 20 countries. BMJ 2020, 368, m108. [CrossRef]

2. Agathokleous, E.; Feng, Z.; Oksanen, E.; Sicard, P.; Wang, Q.; Saitanis, C.J.; Araminiene, V.; Blande, J.D.; Hayes, F.; Calatayud, V.; et al. Ozone affects plant, insect, and soil microbial communities: A threat to terrestrial ecosystems and biodiversity. Sci. Adv. 2020, 6, eabc1176. [CrossRef]

3. Badman, D.; Jaffe, E.R. Blood and air pollution: State of the knowledge and research needs. Otolaryngol. Head Neck Surg. 1996, 114, 205-208. [CrossRef]

4. Kim, C.S.; Alexis, N.E.; Rappold, A.G.; Kehrl, H.; Hazucha, M.J.; Lay, J.C.; Schmitt, M.T.; Case, M.; Devlin, R.B.; Peden, D.B.; et al Lung function and inflammatory responses in healthy young adults exposed to $0.06 \mathrm{ppm}$ ozone for 6.6 hours. Am. J. Respir. Crit. Care Med. 2001, 183, 1215-1221. [CrossRef] [PubMed]

5. Khatri, S.; Holguin, F.C.; Ryan, P.B.; Mannino, D.; Erzurum, S.C.; Teague, W.G. Association of ambient ozone exposure with airway inflammation and allergy in adults with asthma. Asthma 2009, 46, 777-785. [CrossRef] [PubMed]

6. Mortimer, K.; Neugebauer, R.; Lurmann, F.; Alcorn, S.; Balmes, J.; Tager, I. Air pollution and pulmonary function in asthmatic children: Effects of prenatal and lifetime exposures. Epidemiology 2008, 19, 550-562. [CrossRef] [PubMed]

7. Nishimura, K.K.; Galanter, J.M.; Roth, L.A.; Oh, S.S.; Thakur, N.; Nguyen, E.A.; Thyne, S.; Farber, H.J.; Serebrisky, D.; Kumar, R.; et al. Early-life air pollution and asthma risk in minority children. The GALA II and SAGE II studies. Am. J. Respir. Crit. Care Med. 2013, 188, 309-318. [CrossRef]

8. Enweasor, C.; Flayer, C.H.; Haczku, A. Ozone-Induced Oxidative Stress, Neutrophilic Airway Inflammation, and Glucocorticoid Resistance in Asthma. Front. Immunol. 2021, 12, 631092. [CrossRef]

9. Ierodiakonou, D.; Zanobetti, A.; Coull, B.A.; Melly, S.; Postma, D.S.; Boezen, H.M.; Vonk, J.M.; Williams, P.V.; Shapiro, G.G.; McKone, E.F.; et al. Ambient air pollution, lung function, and airway responsiveness in asthmatic children. J. Allergy Clin. Immunol. 2016, 137, 390-399. [CrossRef]

10. Rodopoulou, S.; Samoli, E.; Chalbot, M.G.; Kavouras, I.G. Air pollution and cardiovascular and respiratory emergency visits in Central Arkansas: A time-series analysis. Sci. Total Environ. 2015, 536, 872-879. [CrossRef] [PubMed]

11. Kavouras, I.G.; DuBois, D.W.; Etyemezian, V.; Nikolich, G. Spatiotemporal variability of ground-level ozone and influence of smoke in Treasure Valley, Idaho. Atmos. Res. 2013, 124, 44-52. [CrossRef]

12. Simon, H.; Reff, A.; Wells, B.; Xing, J.; Frank, N. Ozone Trends Across the United States over a Period of Decreasing NOx and VOC Emissions. Environ. Sci. Technol. 2015, 49, 186-195. [CrossRef]

13. Strode, S.A.; Ziemke, J.R.; Oman, L.D.; Lamsal, L.N.; Olsen, M.A.; Liu, J. Global changes in the diurnal cycle of surface ozone. Atmos. Environ. 2019, 199, 323-333. [CrossRef]

14. Henneman, L.R.F.; Shen, H.; Liu, C.; Hu, Y.; Mulholland, J.A.; Russell, A.G. Ozone in the Eastern United States: Production Efficiency Variability Over Time and Between Sources. In Air Pollution Modeling and its Application XXVI. ITM 2018. Springer Proceedings in Complexity; Mensink, C., Gong, W., Hakami, A., Eds.; Springer: Cham, Switzerland, 2020; Chapter 9. [CrossRef]

15. Jin, X.; Fiore, A.; Boersma, K.F.; De Smedt, I.; Valin, L. Inferring Changes in Summertime Surface Ozone-NOx-VOC Chemistry over U.S. Urban Areas from Two Decades of Satellite and Ground-Based Observations. Environ. Sci. Technol. 2020, 54, 6518-6529. [CrossRef]

16. Wells, B.; Dolwick, P.; Eder, B.; Evangelista, M.; Foley, K.; Mannshardt, E.; Misenis, C.; Weishampel, A. Improved estimation of trends in U.S. ozone concentrations adjusted for interannual variability in meteorological conditions. Atmos. Environ. 2021, 248, 118234. [CrossRef] [PubMed]

17. Ren, J.; Hao, Y.; Simayi, M.; Shi, Y.; Xie, S. Spatiotemporal variation of surface ozone and its causes in Beijing, China since 2014 Atmos. Environ. 2021, 260, 118556. [CrossRef]

18. Wilkins, J.L.; de Foy, B.; Thompson, A.M.; Peterson, D.A.; Hyer, E.J.; Graves, C.; Fishman, J.; Morris, G.A. Evaluation of Stratospheric Intrusions and Biomass Burning Plumes on the Vertical Distribution of Tropospheric Ozone Over the Midwestern United States. J. Geophys. Res. Atmos. 2020, 125, e2020JD032454. [CrossRef]

19. Jaffe, D.A.; Wigder, N.; Downey, N.; Pfister, G.; Boynard, A.; Reid, S.B. Impact of Wildfires on Ozone Exceptional Events in the Western, U.S. Environ. Sci. Technol. 2013, 47, 11065-11072. [CrossRef]

20. U.S. Census Bureau. American Community Survey 5-Year Estimates Data Profiles. 2019. Available online: https://data.census. gov / cedsci/table?tid=ACSDP5Y2019.DP05\&g=310XX00US35620. (accessed on 10 December 2021).

21. Ninneman, M.; Jaffe, D. Observed Relationship between Ozone and Temperature for Urban Nonattainment Areas in the United States. Atmosphere 2021, 12, 1235. [CrossRef]

22. United States Environmental Protection Agency Air Data. Pre-Generated Data Files. Available online: https://aqs.epa.gov/ aqsweb /airdata/download_files.html\#Daily (accessed on 8 October 2021).

23. National Interagency Fire Center. Statistics. Available online: https://www.nifc.gov/fire-information/statistics (accessed on 10 December 2021).

24. Chalbot, M.C.; Kavouras, I.G.; Dubois, D.W. Assessment of the Contribution of Wildfires to Ozone Concentrations in the Central US-Mexico Border Region. Aerosol Air Qual. Res. 2013, 13, 838-848. [CrossRef] 
25. Sather, M.E.; Cavender, K. Update of Longterm Trends Analysis of Ambient 8-hour Ozone and Precursor Monitoring Data in the South Central U.S.; Encouraging News. J. Environ. Monit. 2012, 14, 666-676. [CrossRef] [PubMed]

26. Shikwambana, L.; Mhangara, P.; Mbatha, N. Trend Analysis and First Time Observations of Sulphur Dioxide and Nitrogen Dioxide in South Africa Using TROPOMI/Sentinel-5 P Data. Int. J. Appl. Earth Obs. Geoinf. 2020, 91, 102130. [CrossRef]

27. Opio, R.; Mugume, I.; Nakatumba-Nabende, J. Understanding the Trend of $\mathrm{NO}_{2}, \mathrm{SO}_{2}$ and CO over East Africa from 2005 to 2020. Atmosphere 2021, 12, 1283. [CrossRef]

28. Sicard, P.; Paoletti, E.; Agathokleous, E.; Araminienè, V.; Proietti, C.; Coulibaly, F.; De Marco, A. Ozone weekend effect in cities: Deep insights for urban air pollution control. Environ. Res. 2020, 191, 110193. [CrossRef] [PubMed]

29. Sicard, P. Ground-level ozone over time: An observation-based global overview. Curr. Opin. Environ. Sci. Health 2021, $19,100226$. [CrossRef]

30. Yan, Y.; Lin, J.; He, C. Ozone trends over the United States at different times of day. Atmos. Chem. Phys. 2018, 18, 1185-1202. [CrossRef]

31. Baidar, S.; Hardesty, R.M.; Kim, S.-W.; Langford, A.O.; Oetjen, H.; Senff, C.J.; Trainer, M.; Volkamer, R. Weakening of the weekend ozone effect over California's South Coast Air Basin. Geophys. Res. Lett. 2015, 42, 9457-9464. [CrossRef]

32. Coggon, M.G.; Gkatzelis, G.I.; McDonald, B.C.; Gilman, J.B.; Schwantes, R.H.; Abuhassan, N.; Aikin, K.C.; Arend, M.F.; Berkoff, T.A.; Brown, S.S.; et al. Volatile chemical product emissions enhance ozone and modulate urban chemistry. Proc. Natl. Acad. Sci. USA 2021, 118, e2026653118. [CrossRef]

33. Kerr, G.H.; Waugh, D.W.; Sarah, S.A.; Steenrod, S.D.; Oman, L.D.; Strahan, S.E. Disentangling the drivers of the summertime ozone-temperature relationship over the United States. J. Geophys. Res. Atmos. 2019, 124, 10503-10524. [CrossRef]

34. Mason, S.A.; Hamlington, P.E.; Hamlington, B.D.; Matt Jolly, W.; Hoffman, C.M. Effects of climate oscillations on wildland fire potential in the continental United States. Geophys. Res. Lett. 2017, 44, 7002-7010. [CrossRef] 